\title{
Predation on Earthworms (Oligochaeta) by Cuban Brown Anoles, Anolis sagrei (Squamata: Dactyloidae)
}

\author{
Manuel Iturriaga and Luis F. de Armas
}

Instituto de Ecología y Sistemática, Carretera de Varona No. 11835, entre Oriente y Lindero, Reparto Parajón, Municipio Boyeros, La Habana 19, C.P. 11900, Cuba(manueliturriaga@ecologia.cu; luisdearmas1945@gmail.com)

A though frugivory (e.g., Simmon et al. 2005; Fläschendräger and Wijffels 2009) and nectarivory (e.g., Colón 2010; Cajigas-Gandia et al. 2018) have been reported, anoles usually prey on insects and other arthropods (e.g., arachnids, terrestrial isopods, millipedes, centipedes) and occasionally consume mollusks and small vertebrates, including congeners and conspecifics (e.g., Henderson and Powell 2009 and references therein; Rodríguez-Cabrera and Fong 2015). Among West Indian species, the Hispaniolan Stout Anole (Anolis cybotes), Puerto Rican Crested Anole (A. cristatellus), Puerto Rican Giant Anole (A. cuvieri), Puerto Rican Yellow-chinned Anole (A. gundlachi), and Dominica Anole (A. oculatus) are known to prey on earthworms (Henderson and Powell 2009 and references therein).

During the summer of 2018, we observed three incidents of Cuban Brown Anoles (A. sagrei) preying on earthworms in the backyard of a residence in San Antonio de los Baños $\left(22^{\circ} 53^{\prime} 36.49^{\prime \prime} \mathrm{N}, 82^{\circ} 30^{\prime} 35.21^{\prime \prime} \mathrm{W} ; 75 \mathrm{~m}\right.$ a.s.l.), Artemisa Province, Cuba. The first observation at 1035 h on 13 July involved an adult male, perched on a stone $20 \mathrm{~cm}$ above the substrate, consuming an earthworm (Fig. 1A).

A second observation at $1527 \mathrm{~h}$ on 8 August involved an adult female (SVL approx. $50 \mathrm{~mm}$ ) on the ground eating an earthworm nearly $80 \mathrm{~mm}$ in length. When the lizard grasped it, it broke in two parts. The lizard then ate the first part and later the other one. Complete consumption lasted about $10 \mathrm{~min}$.

The last observation was at $1236 \mathrm{~h}$ on 1 September and likely involved the same female observed in August. On this occasion, the lizard, perched on the rim of a metallic potsherd $23 \mathrm{~cm}$ above the substrate, was eating an earthworm $47 \mathrm{~mm}$ in length and $57 \mathrm{~mm}$ in diameter (Fig. 1B). Consumption lasted about $15 \mathrm{~min}$.

Because $A$. sagrei is a definitive sit-and-wait predator (e.g., Schwartz and Henderson 1991; Rodríguez-Schettino 2003), the earthworms probably were captured above the ground, perhaps forced to the surface by water saturating the soil. Moreover, three observed cases in the span of a month and a half suggest that earthworms might be relatively common
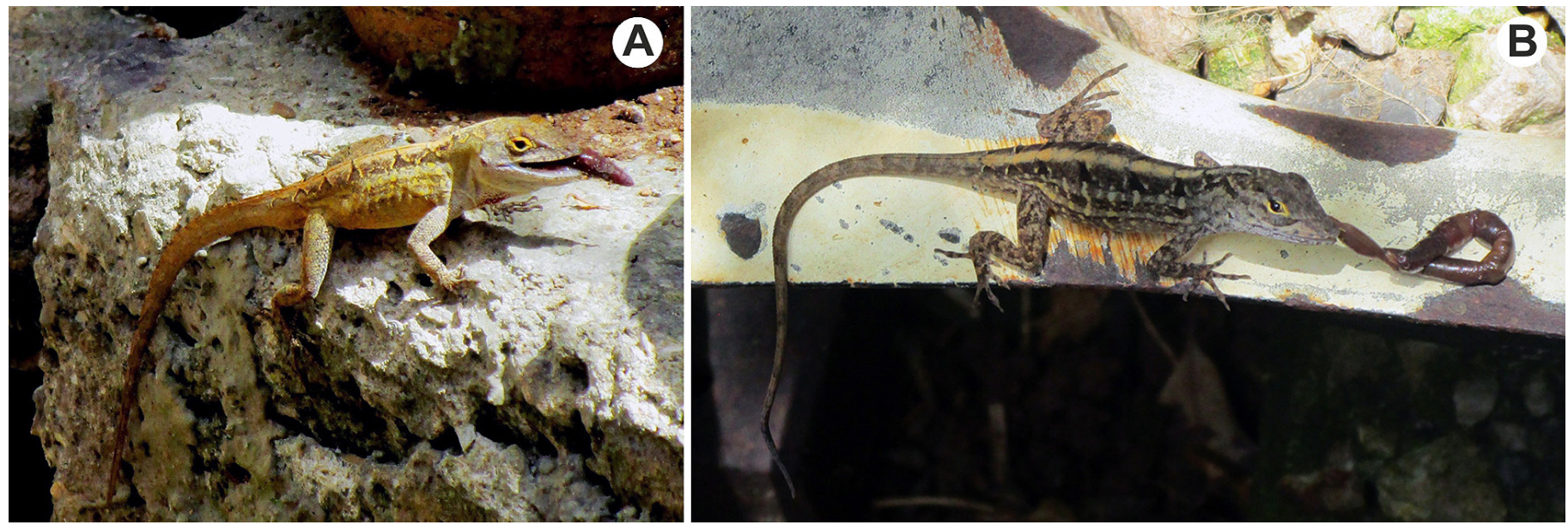

Fig. 1. Predation on earthworms by Cuban Brown Anoles (Anolis sagrei) in a residential backyard in San Antonio de los Baños, Artemisa Province, Cuba on 13 July 2018 (A) and 1 September 2018 (B). Photographs by Luis F. de Armas. 
prey of $A$. sagrei. Certainly, earthworms, which are rich in lipids and proteins (e.g., Brusca and Brusca 2003), represent a highly nutritious resource for lizards.

\section{Acknowledgements}

We are indebted to Antonio Cádiz and Sonia Seuc for critical reviews of this manuscript.

\section{Literature Cited}

Brusca, R.C. and G.J. Brusca. 2003. Invertebrates. 2nd ed. Sinauer Associates, Inc., Sunderland, Massachusetts.

Cajigas-Gandia, A., J. Reina-Carvajal, and J. Torres-López. 2018. An instance of nectarivory in a Cuban Green Anole, Anolis porcatus (Squamata: Dactyloidae). Reptiles \& Amphibians 25: 37-39.
Colón, A.D. 2010. Nectarivory in Puerto Rican Emerald Anoles (Anolis evermanni). Reptiles \& Amphibians 17: 144-145.

Fläschendräger, A. and L.C.M. Wijffels. 2009. Anolis. 2. vollständig überarbeitete und erweitere Auflage. Natur und Tier, Münster, Germany.

Henderson, R.W. and R. Powell. 2009. Natural History of West Indian Reptiles and Amphibians. University of Florida Press, Gainesville.

Rodríguez-Cabrera, T. M. and A. Fong G. 2015. Predation on a blindsnake genus Typhlops (Squamata: Typhlopidae) by the Spanish Flag Anole, Anolis allogus (Squamata: Dactyloidae) in Cuba. Reptiles \& Amphibians 22: 156-159.

Rodríguez-Schettino, L. (ed.). 2003. Anfibios y Reptiles de Cuba. UPC Print, Vaasa, Finland.

Schwartz, A. and R.W. Henderson. 1991. Amphibians and Reptiles of the West Indies: Descriptions, Distributions, and Natural History. University of Florida Press, Gainesville.

Simmons, P.M., B.T. Greene, K.E Williamson, R. Powell, and J.S. Parmerlee, Jr. 2005. Ecological interactions within a lizard community on Grenada. Herpetologica 61: 124-134 